\title{
What does it mean to call yourself a Christian? Some philosophical reflections on the Christian identity
}

\begin{abstract}
In my discussion of Brümmer's article on the Identity of the Christian Tradition I argue that it is necessary to complement an external approach of this question, which tries to lay down the essential characteristics of the Christian tradition, with an internal one, which interprets the Christian identity as the result of a personal identification with a given tradition through a process of re-interpretation. In order to show the new insights that such an internal approach can yield I comment on Brümmer's analysis of three important paradigms concerning the identity of the Christian tradition. This results in an idea of the Christian identity as a dynamic unity of a given tradition and its constant re-interpretations, which enable people to identify themselves with this tradition. Only this approach is able to explain the way in which many people experience nowadays their religious identity, viz. as belonging without believing.
\end{abstract}

\section{INTRODUCTION}

In his valedictory lecture of 1997 Vincent Brümmer addressed the intriguing question of the identity of the Christian tradition. ${ }^{1}$ At that time, nobody could expect that, some fifteen years later, the issue of identity would be of such importance in the public debate. Nowadays, people are preoccupied with their personal and collective identity, including the expressions (e.g. symbols, ways of behaving) that manifest it. The way in which this preoccupation takes shape highlights at least one striking difference with Brümmer's approach: whereas the focus of his paper was - largely, although not exclusively - on the identity of the Christian tradition, the public and scholarly debate is these days focused on the (Christian) identity, on the question what is at stake when believers identify themselves with a religious tradition. So, the focus of the debate has somehow shifted from an (external or objective) analysis of the essential characteristics of the Christian tradition towards the question of why a person (internally or subjectively) identifies himself as Christian. The answer that one nowadays most commonly gets when inquiring into this 'why' is by and large a certain feeling of belonging to this tradition, rather irrespective of its objective content. Social scientists summarize this attitude as (a subjective feeling of) belonging without believing (in the objective doctrine of Christianity). This focus on the internal or subjective aspect of the Christian identity, as distinct from the objective identity of the Christian tradition, will play an important role in my comment on Brümmer's position. However, I will not only try to shed some light on what is philosophically at stake when people call themselves Christians, but - especially in the last section - also aim to contribute to the discussion about the identity of the Christian tradition.

1 Vincent Brümmer, The Identity of the Christian Tradition. In: Vincent Brümmer, Brümmer on Meaning and the Christian Faith. Collected Writings of Vincent Brümmer. Ashgate, Aldershot, 2006, 375-390. 
http://ngtt.journals.ac.za

\section{A COMMENT ON BRÜMMER'S ANALYSIS OF THE IDENTITY OF THE CHRISTIAN TRADITION}

Brümmer's point of departure in his very illuminating analysis of the identity of the Christian tradition is that the Christian message is not bound to one single language or culture, but can be expressed in all languages and in the conceptual forms of every culture. Hence, Christianity had from its very beginnings to deal with the question of its universality in a context of linguistic and cultural plurality, thus making the problem of an adequate translation and re-interpretation of her message in a new spiritual-cultural environment one of its central concerns. ${ }^{2}$ Finding an answer to this problem is essential for the identity of the Christian tradition. In his essay, Brümmer discusses three influential philosophical paradigms that intend to solve the tension between the identity of the Christian tradition and its permanent need for re-interpretation.

\section{Identity and essence}

This paradigm explains the identity of the Christian tradition in terms of an essence (or substance) that remains the same throughout the times, while its accidental features can vary and change without affecting the essence of this tradition. Brümmer's main problems with this distinction between essential and accidental properties are that we have no obvious or universally recognised criteria for making this distinction, and, secondly, that there are hardly any tenets of the Christian faith that have been free of re-interpretation. ${ }^{3}$ This raises the question whether it still makes sense to speak of the unchangeable identity of the Christian tradition at all, or that everything is subject to interpretation, which would, following this line of interpretation, jeopardize the very idea of Christian identity. Brümmer tries to solve this problem in a pragmatic way by pointing out that "it is impossible for all aspects of someone's faith to be modified at the same time," 4 but he also admits that there is no guarantee that the supposedly unchangeable beliefs will not sooner or later be re-interpreted themselves, so that in the end there would be no unchangeable essence left.

In addition to Brümmer's argument I want to show in a more principled way the limits of the approach that underlies the position that the Christian identity would be equivalent to an unchangeable essence. From an external perspective, it may be correct to understand a re-interpretation of the Christian tradition simply in terms of change, and, if this change is more than marginal, as an annihilation of its identity. But such an approach fails to understand the reasons why and the intentions with which Christians re-interpret their tradition. For the Christians themselves, re-interpretation by no means coincides just with change and even less with a loss of their identity. On the contrary, only through a process of re-interpretation can Christians identify themselves with their tradition By doing so, they make it their own in the specific spiritual-cultural environment in which they live. It is important to note here that this identification is always a two-way process: I not only identify myself with a given tradition, but my social environment also identifies me with this tradition, sometimes even against my own will, or on grounds that I myself am unaware of. In sum, from an internal perspective, identity requires identification, making a given tradition one's own, familiarizing oneself with it, and this can only be done through re-interpreting it in new spiritual-cultural contexts. ${ }^{5}$

Secondly, if we accept the idea that the Christian identity depends on one's identification with

2 Brümmer, The Identity of the Christian Tradition, $375 \mathrm{ff}$.

3 Brümmer, The Identity of the Christian Tradition, $380 \mathrm{f}$.

4 Brümmer, The Identity of the Christian Tradition, 382.

5 See Peter Jonkers, Orthopraxis and Being Faithful to One's Tradition. In: Bob Becking (ed.), Orthodoxy, Liberalism, and Adaptation. Essays on Ways of Worldmaking in Times of Change from Biblical, Historical and Systematic Perspectives (Studies in Theology and Religion 15). Brill, Leiden, 2011, 205-223. 
the Christian tradition, which essentially takes shape through re-interpretation, this should not be misunderstood as a purely subjective activity of (re)constructing or tinkering heterogeneous elements from various sources at will. Re-interpreting a (religious) tradition always refers the interpreter back to the tradition to which he or she is committed. As the meaning of the Latin word tradere shows, tradition refers to something that is handed down to us, something that is entrusted to our care. The fact that believers acknowledge that their identity depends on their identification with the Christian tradition shows that the latter is of a normative existential value to them: it helps them to orientate themselves in their lives, because this tradition serves for them as an exemplary way to organise and structure all aspects of human life on the basis of symbolic distinctions between what is good and valuable and what is not. This analysis of the reasons why a tradition deserves to be respected enables me to criticize the nowadays popular tendency to treat traditions as nothing but raw material, at our disposal for endless re-descriptions of ourselves and the world around us. We do not so much construe traditions as they construe us, in the sense that they enable us to situate ourselves in a cultural space and time, and hence to form our identity. ${ }^{6}$ Finally, the 're-' in the term re-interpretation makes clear that the interpretation of a tradition is an ongoing process, so that it cannot be confined to the current generation of interpreters. Because it is so massive and vast, a tradition always transcends the people who are interpreting it.

In sum, through my internal approach of the Christian identity I have shown that identity cannot be reduced to a fixed set of principles, constituting the unchangeable essence or core identity of the Christian tradition. This does not mean that all elements of the Christian tradition are equally important, and even less that any re-interpretation is as good as any other. But the above analysis does show that a sharp distinction between an unchangeable essence and its contingent manifestations or between identity and re-interpretation does not hold. Moreover, the thesis of the close link between identity and re-interpretation does not only rest on pragmatic grounds, as Brümmer argues, but also on principled reasons. My proposal to understand the Christian identity as the result of a personal identification with the Christian tradition through reinterpreting it turns identity into a dynamic concept, as distinct from the static view of identity as essence. But this proposal also aims at preserving this tradition as an existential point of reference for believers: identifying oneself as a Christian is always an identification with a given tradition, to which Christians are committed and for which they hence are responsible.

\section{Identity and continuity}

According to this paradigm, a religious tradition is not an immutable and monolithic system of religious ideas, but a historical process of transmission of and familiarisation with this tradition by the believers. From this perspective, the Christian tradition is a cumulative process, characterised by continuity, as well as by pluralism and change. According to Brümmer (and my analysis of the Christian identity in the previous section shows that I agree with him in this respect), the personal faith of believers is conditioned, but not completely determined by their tradition, because it adds an authentic re-interpretation to this tradition, which can be seen as its prolongation and enrichment. ${ }^{7}$ The result is that a religious tradition consists of a series of overlapping chains of events, which are not identical but have a lot in common. However, Brümmer sees some fundamental problems regarding the identity of the Christian tradition, ensuing from this paradigm.

First of all, the further such chains of events are historically removed from each other,

6 Odo Marquard, Apologie des Zufälligen. Philosophische Überlegungen zum Menschen. in idem, Zukunft braucht Herkunft: Philosophische Essays. Reclam, Stuttgart, 2003, 154.

7 Brümmer, The Identity of the Christian Tradition, $383 \mathrm{f}$. 
the less they have in common, so that, eventually, a religious tradition is identified with its contingent history. One can argue that faith always transcends these contingencies, since it testifies to the abiding presence of God's Spirit, but the trouble with this idea is "that it makes the identity of a religious tradition a matter of faith rather than sight." 8 Consequently, one lacks the phenomenological criteria to assess which events in religious history are actually inspired by God's Spirit and which ones are not. In order to solve this problem, one can argue that the unity and coherence of a religious tradition is that of an 'enacted narrative', so that a religious tradition has a self-corrective potential that does not exclusively rely on the faith in or the claim on the working presence of God's Spirit. According to Brümmer, these considerations are helpful to explain the continuity, but not the identity of a religious tradition, since to see this tradition as an interaction between the members of a community of believers throughout the ages does not explain who is to count as a member of this community, because these members also interact with non-members. ${ }^{9}$

I think that Brümmer's argument, however valid it is, again shows the limits of an external approach for the understanding of the Christian identity. Asking for objective criteria to define the identity of a religious tradition in order to determine who is a member of it and who is not, is a demand that no tradition can fulfil and nor should be willing to do so. ${ }^{10}$ First of all, criteria are not 'loosely obtainable goods', which means that they cannot be severed from the tradition they are supposed to define. The Confession of Faith is the summary of the Christian tradition, and, thus, plays a crucial role in defining the identity of this tradition. But this Confession cannot be severed from its interpretation by the Christian tradition throughout the ages. Moreover, there are a lot of Christians who have their doubt about this or that specific article of their faith, and yet consider themselves as committed Christians. This shows that asking for objective criteria to define the identity of the Christian tradition confronts it with a demand it cannot possibly fulfil. Moreover, the Christian tradition should not even be willing to accept such an objective criterion in order to distinguish insiders from outsiders. The term 'Confession of Faith' does not only refer to its objective content, i.e. the Christian faith, but also to Christians who confess it, that is who testify to their personal commitment to this tradition. One can even argue that the fact that Christians identify themselves as Christian by confessing their faith is more important for their identity than knowing the exact theological ins and outs of the articles of faith. This shows that the issue of the identity of the Christian tradition refers us back to the question of people identifying themselves as Christians, without thereby wanting to suggest that the former could be replaced by the latter.

So, following my suggestion of an internal approach, a personal identification with a given tradition has the advantage of defining identity in terms of a dynamic unity. The aspect of believers' belonging to a tradition enables them to communicate and discuss its (true) nature, and exemplifies its normative character; the aspect of their belonging to a tradition enables believers to identify themselves personally with this tradition. In sum, defining the Christian identity in terms of a dynamic unity of an objective tradition and a personal identification allows us to understand how this tradition can serve as a normative point of reference in the lives of Christians, but also helps to explain how people can come to terms with a (radical) reinterpretation of their tradition without losing their identity.

8 Brümmer, The Identity of the Christian Tradition, 384.

9 Brümmer, The Identity of the Christian Tradition, 386.

10 I am fully aware of the fact that quite a lot of religious leaders in various traditions think differently about this issue, and want to formulate criteria, with which they can unambiguously distinguish the true believers from the rest. In the final section of this paper, when discussing the problems of a 'realistic' approach of the Christian identity, I will come back to this issue. 
Let me give an example of the relation between the identity of the Christian tradition and radical re-interpretation. The attitude of the Catholic Church, both in its doctrines and its practices, with regard to other Christian denominations and non-Christian religions has changed considerably since the second Vatican Council. The Catholic Church had a long-standing tradition of clinging to the universal truth of its message of salvation, which implied that it excluded other religious and secular convictions from salvation. As some Church leaders officially declared as late as the first half of the $20^{\text {th }}$ century: 'An error has no rights'. However, the second Vatican Council decided that the Church had to accept some basic principles of modern society, particularly the state-church separation and the freedom of religion, being important articles of the Universal Declaration of Human Rights. This resulted in Pope Paul VI's declaration on religious freedom, entitled Dignitatis humanae (1965). In this text, he recognises that religious freedom belongs to the very dignity of human beings, and declares it "to be greatly in accord with truth and justice. To this end, it [i.e. the Vatican Council] searches into the sacred tradition and doctrine of the Church - the treasury out of which the Church continually brings forth new things that are in harmony with the things that are old."11

The above is obviously an example of a radical re-interpretation of the identity of the Christian tradition, and this on the level of the official doctrine of the Church as well as on that of its concrete practices. From an external perspective, this radical re-interpretation can hardly be seen as a sign of the continuity of the Christian tradition, and thus poses a serious problem for its identity. Is it possible to make sense of this re-interpretation in connection with the Christian identity from an internal perspective? The above quote gives a clear definition of what a re-interpretation of the Christian tradition (including its doctrine) means for Christians, and explains how it is related to their identity. In their eyes, tradition is a treasury that helps them to give meaning and orientation to their lives, even in a completely new cultural situation. In the above example, the Church has taken a new cultural context, that of religious pluralism, as its starting point to re-interpret the Christian tradition, and has urged Christians to redefine their personal and political relations with people adhering to different faiths. This redefinition is essential for their Christian identity, since it enables them to continue identifying themselves with the Christian tradition in a radically new cultural situation. The word 'treasury' from the above quote highlights the fact that the normative value of a tradition is the result of it being an inexhaustible source of meaning in new situations. Hence, what defines the Christian identity is the capacity of Christians to draw from the source of their tradition always new spiritual food that gives meaning to their lives in new situations.

In sum, from an external perspective one can objectively assess the degree of (dis)continuity of the new doctrine and practice with the established body of older doctrines and practices, called 'the tradition', inevitably leading to the conclusion that in this specific case the identity of the Christian tradition has become problematic. But from an internal point of view the crucial question is rather whether the Christian tradition is still able to serve as a source of meaning for people in a new cultural context, so that it still makes sense to commend one's life to God. The above quote also explains which 'new things' the Vatican Council brings forth out of the treasury of her tradition in order to assist people in re-interpreting their faith: they concern the belief that all human beings, regardless of their differences in religious convictions, are God's creatures and hence are vested with the same dignity, which must be respected unconditionally. Thus, this example shows that the Christian identity does not depend as such on the objective degree of (dis)continuity of the tradition over a certain period of time, but rather on the question of whether people are able to find elements in a given tradition that serve as a source of meaning in a new cultural situation, so that they can continue to call themselves Christian.

11 Pope Paul VI, Dignitatis humanae, 1. 
Of course, the problem of the loss of identity is as fundamental from an internal perspective on the Christian identity as is it is from an external analysis, yet it is dealt with in a different way. From an internal point of view, the reason that people lose their religious identity is not so much a consequence of the objective lack of continuity in the Christian tradition over a longer period of time, as the above example has made clear. It rather results from the fact that, for example, believers have been confronted with a devastating experience that has shattered their capability to link this experience, and, by extension, their lives to this tradition, to continue to see it as a source of inspiration and orientation. One of the most tragic examples of this is based upon the experience of Auschwitz, in particular of the manifold ways in which the Nazis deliberately tried to annihilate every aspect of human dignity. Many people experienced this as a 'proof' of the complete absence of God. As a consequence, they were incapable (even many years after the war) to re-interpret this experience in terms of the Jewish and Christian tradition and to continue commending their lives to such an absent God. This inevitably resulted in the loss of their Jewish and Christian identity, and this not so much on the basis of an objective lack in the continuity of these traditions, but because of the incapacity to give this experience a place, any place, in their religious narratives.

\section{Identity and origin}

The final and, as far as Brümmer is concerned, most preferable way to define the identity of the Christian tradition is to see it as "the narrative continuity of the historical process of interpretation that starts in the Bible itself and refers to the connected series of events telling the impact of Jesus Christ, who is acknowledged by believers to be the fixed origin of the tradition as well as the paradigmatic locus of meaning for human existence."12 This approach, which stems from insights of Kripke and Sykes, combines two aspects of the Christian tradition: 1) it is not a timeless and immutable reality, but requires re-interpretation, and hence is able to change and give rise to new versions of itself, and 2) yet, it has a fixed origin, viz. the life and death of Jesus Christ, which serves as the point of reference for every re-interpretation. The confession of faith and the life lived in obedience to this commitment testify to the authoritative character of this origin. This means that the unity and identity of the Christian tradition is constituted by the shared reference to the achievement of a single original exemplar acknowledged by all participants as the original locus of meaning. ${ }^{13}$

At this point, Brümmer's approach to the identity of the Christian tradition comes quite close to my own analysis of Christian identity as an expression of an existential commitment to a given tradition. However, I disagree with him that the life and death of Jesus Christ is the fixed, authoritative origin of Christianity. In my view, these events cannot be dissociated from their interpretation by the Christian community of faith throughout the ages, and hence, cannot serve as the fixed origin and point of reference of the identity of Christianity. I am even afraid that the result of Brümmer's search is the opposite of what he wants to demonstrate.

First, the identity of the Christian tradition does not so much lie in the objective fact that a certain person, Jesus of Nazareth, lived and died in Palestine some two thousand years ago, a fact that is confirmed by biblical as well as by extra-biblical sources. Far more important is the belief that Jesus is the only son of God, that he rose from the dead on the third day, ascended into heaven and is seated at the right hand of the Father, as the text of the Confession of Faith reads. In other words, Christmas, the day of Jesus' birth, is only crucial to the identity of the Christian tradition because of Easter, the day of the resurrection. But Christ's resurrection is not in the same way a fixed point of origin as his life and death. Rather, it is an interpretation by the

12 Brümmer, The Identity of the Christian Tradition, 389.

13 Brümmer, The Identity of the Christian Tradition, 387. 
Evangelists of some puzzling experiences of the disciples after Jesus' death, and not the fixed point of origin for every interpretation, as Brümmer wants to have it.

Second, the Apostles' Creed (Symbolum Apostolorum), which has been generally accepted as the authoritative summary of the identity of the Christian tradition, was the result of - sometimes fierce - theological debates in the early Church about the interpretation of the true nature of Christ. This means that the Confession of Faith is itself a re-interpretation of the New and - to a lesser extent - the Old Testament, but not the fixed origin of Christianity that Brümmer is looking for. Moreover, throughout the history of Christianity, the Confession of Faith has been the subject of a continuous process of new re-interpretations.

In sum, the stories about the life, death and resurrection, as handed down in the Gospels, and the Confession of Faith rather belong to the Christian tradition than that it could serve as a point of reference for it. This implies that it is impossible to dissociate one specific element from a broader context, viz. the Christian tradition, and call that element the fixed origin of this tradition. Actually, there is no normative point of reference outside this tradition, but only a tradition, with which Christians identify themselves. Within this tradition a pivotal place has been attributed to the life, death and resurrection of Jesus Christ, because he is believed to manifest in an exemplary and unique way who God is. So, I agree with Brümmer's conclusion that "the unity and identity of the Christian tradition can be found in the narrative continuity of the historical process of interpretation that starts in the Bible itself and refers to the connected series of events telling the impact of Jesus Christ [...] as the paradigmatic locus of meaning for human existence," but not with his contention that Jesus Christ is the 'fixed origin' of that tradition, thus suggesting that the Christ event lies outside that tradition. ${ }^{14}$ I rather agree with Sykes view that the Christian tradition is an ongoing dispute about the meaning and interpretation of this term, implying that there is no fixed point of origin outside this tradition.

\section{THE IDENTITY OF THE CHRISTIAN TRADITION}

In order to further develop this issue, which is not only of crucial importance for the identity of the Christian tradition, but also for national, ethnic and even personal identity, I want to make a distinction between a symbolic and a realistic approach to identity. ${ }^{15} \mathrm{~A}$ symbolic approach links a (material) object or event with its symbolic interpretation by a cultural community. The two cannot be dissociated from each other. Paraphrasing Kant one could say that a pure fact that lacks any interpretation remains blind or meaningless, and that a symbol without any reference to what is being interpreted remains empty. In the case of the identity of the Christian tradition this means that factual objects or (series of) events, such as the life and death of Jesus, offer the necessary content for every symbolic interpretation. But in order to become a point of reference or a paradigm for the identity of the Christian tradition a community of believers has to attribute a symbolic meaning to this object or event, by interpreting Jesus as God's only son, who did not only live and die, but also has risen from the dead, thus foreshadowing our own resurrection at the end of times.

This elucidation of the close relation between a contingent fact and its symbolic interpretation also explains why a seemingly minor violation of the former can have such a disruptive effect on one's (Christian) identity. Examples abound in this respect: desecrating a church, poking fun at a liturgical service, ridiculing the Bible, all those acts are far more disruptive for the Christian

14 Brümmer, The Identity of the Christian Tradition, 389.

15 For this distinction, as well as for its further development, I am indebted to Arnold Burms, Het eigene. Reëel of symbolisch. In: Roland Breeur and Arnold Burms, Ik / Zelf. Essays over Identiteit en Zelfbewustzijn. Peeters, Leuven, 2000, 125-145. 
identity than what one would expect if one only takes the materiality of these events into account. Their vital role for the constitution of the Christian identity results from the symbolic interpretation of these events from within the Christian tradition, and cannot be understood apart from this interpretation. Again, this means that it makes no sense to speak about a 'fixed origin' of the Christian identity apart from its interpretation, and to found this identity on some 'real' properties that can be univocally determined.

The hopeless search, in my view, for a fixed origin of the Christian identity takes us to the more general problems of a 'realistic' approach to identity. Such an approach runs the risk of inadvertently solidifying and homogenizing the identity of the Christian tradition. In order to explain this issue I give an example stemming from a non-religious context, viz. national identity. It is common knowledge that nationality is an important element of one's identity, and this in spite of or rather due to the ongoing process of globalisation. Moreover, one's national identity includes far more than an indication on one's passport, which, perhaps, is the only 'real', fixed ground for one's nationality. But it is also clear that this 'more' lacks such a realistic basis, and, hence, cannot be defined unambiguously. The consequence of this lack of a 'real' foundation of national identity is that it does not make sense and is even impossible to speak of the identity of a nation, as if it were a fixed point of reference, something that could be defined unambiguously. The identity of the Dutch society resembles the English, French or German ones in many respects, but also differs from them, e.g. through its language, traditions, political system, history, size etc. But if one wants to delineate this identity precisely and unambiguously, it is hard to come any further than some well-known stereotypes. Furthermore, national characteristics may apply to some citizens, but not to all of them, or may occur in various degrees, etc. But this does not lead to making the attribution of the Dutch identity dependent on determining whether people reach a minimal threshold regarding these features. The same holds true with religious identities: many people call themselves Catholic, Protestant, Jewish or Muslim, although they do not follow all the doctrinal and ritual guidelines of the religious community they belong to. This again shows that it is as problematic to speak about a fixed, 'real' criterion for a religious identity as it is for a national identity. Moreover, (partly) founding the identity of a religious tradition or a nation on a number of 'real', objective points of reference means that these (material) things, words, gestures and practices lose their symbolic character, and start to serve as the actual essence of these identities, requiring strict observance by all the members of a community. This inevitably starts off a process of homogenization, often in combination with segregation, in which one's identity is reduced to a kind of objective checklist, which can be ticked off. ${ }^{16}$

The reasons that some religions and - more generally - contemporary society as such tend to ignore the symbolic dimension of (religious) identity are twofold. First of all, there is the widespread ideal of individual autonomy, according to which every single aspect of our identity is thought to depend on ourselves. But, as I pointed out above, I do not master all aspects of my (religious) identity, but I identify myself with a given tradition, which can be defined as an inexhaustible treasury from which I draw, and which rather forms my identity than vice versa. Secondly, there is the engrained tendency of humans to replace the symbolic with the real or to see the latter as the justification of the former. Using an objective checklist in order to define someone's religious identity unambiguously is one of the most striking examples of this tendency. Our reasons for doing so is that this strategy is so reassuring, since it enables

16 I developed this issue further in: Peter Jonkers, The Dialectics of Cultural Pluralism and Social Cohesion. In: Niek Brunsveld and Roger Trigg (ed.), Religion in the Public Sphere. Proceedings of the 2010 Conference of the European Society for Philosophy of Religion (Ars Disputandi, Supplement Series, $n r$. 5). Ars Disputandi, Utrecht, 2011, 177-186 (URL: http://adss.library.uu.n1/publish/articles/000085/ bookpart.pdf). 
us to make clear cut distinctions between insiders and outsiders, friends and foes. But at the same time it is obvious that this approach negates the impalpability of religious, national, etc. identities as symbolic systems of meaning.

\section{CONCLUSION}

My discussion of Brümmer's essay on the identity of the Christian tradition has resulted in two essential insights. First of all, in order to get a complete view of this identity, one has to supplement the external, objective approach of this identity with an internal, subjective one, which focuses on the personal identification with this tradition. Only this approach is able to understand the religious identity of so many people in contemporary society: they have a fundamental sense of belonging to this tradition without believing some of its essential doctrines. Secondly, in order to avoid a senseless homogenization of the identity of a (religious) tradition, often combined with a problematic tendency to fence off one's own religious identity from that of other people, it has to be interpreted symbolically, i.e. as the result of a cultural system of meanings and distinctions, which always escapes our control and sometimes even eludes our notice.

\section{BIBLIOGRAPHY}

Vincent Brümmer, The Identity of the Christian Tradition. In: Vincent Brümmer, Brümmer on Meaning and the Christian Faith. Collected Writings of Vincent Brümmer. Ashgate, Aldershot, 2006, 375-390.

Arnold Burms, Het eigene. Reëel of symbolisch. In: Roland Breeur and Arnold Burms, Ik / Zelf. Essays over Identiteit en Zelfbewustzijn. Peeters, Leuven, 2000, 125-145.

Peter Jonkers, Orthopraxis and Being Faithful to One's Tradition. In: Bob Becking (ed.), Orthodoxy, Liberalism, and Adaptation. Essays on Ways of Worldmaking in Times of Change from Biblical, Historical and Systematic Perspectives (Studies in Theology and Religion 15). Brill, Leiden, 2011, 205223.

Peter Jonkers, The Dialectics of Cultural Pluralism and Social Cohesion. In: Niek Brunsveld and Roger Trigg (ed.), Religion in the Public Sphere. Proceedings of the 2010 Conference of the European Society for Philosophy of Religion (Ars Disputandi, Supplement Series, nr. 5). Ars Disputandi, Utrecht, 2011, 177186 (URL: http://adss.library.uu.nl/publish/articles/000085/bookpart.pdf).

Odo Marquard, Apologie des Zufälligen. Philosophische Überlegungen zum Menschen. in idem, Zukunft braucht Herkunft: Philosophische Essays. Reclam, Stuttgart, 2003, 146-168.

\section{KEY WORDS}

Christian identity

Tradition

Identification

Paradigms of identity

Symbolic versus 'real' identity 